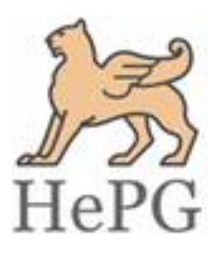

ISSN: 2348-1900

Plant Science Today

http://www.plantsciencetoday.online

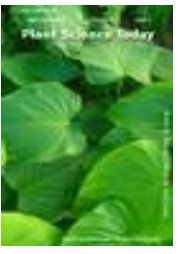

OPE

Research Article

\title{
Ethnobotanical and ethnoecological study of the most important edible, medicinal and industrial species in the grasslands of Khalil Abad region, Zarrin Dasht, Fars province, Iran
}

\author{
Kourosh Kord ${ }^{1}$, Fatemeh Abedi ${ }^{2}$, Hamidreza Kazemeini ${ }^{3}$, Somayeh Shahsavari ${ }^{4}$ \& Kamal Solati $^{*}$ \\ ${ }^{1}$ Rajiv Gandhi University of Health Sciences, Bangalore, India \\ ${ }^{2}$ Khatam-ol-Anbia University of Technology Behbahan, Behbahan, Iran \\ ${ }^{3}$ Department of Food Hygiene, Faculty of Veterinary Medicine, Amol University of Special Modern Technologies, Amol, Iran \\ ${ }^{4}$ Biotechnology and Medicinal Plants Research Center, Ilam University of Medical Sciences, Ilam, Iran \\ ${ }^{5}$ Shahrekord University of Medical Sciences, Shahrekord, Iran
}

\section{Article history}

Received: 12 April 2019

Accepted: 10 May 2019

Published: 30 June 2019

\section{Publisher}

Horizon e-Publishing Group

\section{*Correspondence}

Kamal Solati

品latik@ymail.com

\begin{abstract}
It is vital to record and preserve indigenous knowledge on plants to prevent loss of this valuable information. The indigenous knowledge about herbal drugs can provide us with useful information, such as their phytotherapeutic activities for the treatment of various diseases. This study investigated the indigenous knowledge regarding the use of medicinal plants for the treatment of human diseases and disorders in Khalil Abad region, Zarrin Dasht County, Fars province (Iran) from January to May 2017. Questionnaires were distributed among the subjects and traditional herbal information were recorded. The medicinal plants in this region are predominantly bush, including Zataria multiflora Boiss, Peganum harmala L., Alhagi persarum Boiss. \& Buhse and Astragalus sp. The results of this study indicate that the residents of Khalil Abad village use various medicinal plants for nutritional and medicinal purposes. This is the first report of the ethnobotany of the region and the medicinal plants of indigenous knowledge of this region could be used as a source for new drugs.
\end{abstract}

Keywords: Herbal plants; Fars province; Iran; Ethnobotany; Traditional remedies.

Citation: Kord K, Abedi F, Kazemeini H, Shahsavari S, Solati K. Ethnobotanical and ethnoecological study of the most important edible, medicinal and industrial species in the grasslands of Khalil Abad region, Zarrin Dasht, Fars province, Iran. Plant Science Today 2019; 6(2):275-280. https://doi.org/10.14719/pst.2019.6.2.551

Copyright: (C) Kord et al (2019). This is an open-access article distributed under the terms of the Creative Commons Attribution License, which permits unrestricted use, distribution, and reproduction in any medium, provided the original author and source are credited (https://creativecommons.org/licenses/by/4.0/).

Indexing: Plant Science Today is covered by Scopus,Web of Science, BIOSIS Previews, ESCI, CAS, AGRIS, CABI, Google Scholar, etc. Full list at http://www.plantsciencetoday.online

\section{Introduction}

Medicinal plants are an important part of every country's natural resources and the collection and codification of traditional information about natural resources is a requirement of every human society. The people's attitudes towards the natural resources and the ways they use them can contribute greatly for restoring or destroying these resources (1). In fact, indigenous knowledge about 
the use of medicinal plants for the treatment of various diseases dates back to the beginning of human civilization (2). According to World Health Organization statistics, $84 \%$ of the population of developing countries primarily use native medicinal plants for primary health care. For example, Pakistan's population is predominantly dependent on 600 medicinal plants (out of a total of 5700 plant species) for primary health care $(3,4)$. Similarly, the indigenous knowledge about medicinal plants plays an important role in the local health care system $(5,6)$. Native medicinal plants are usually traditionally used and mainly screened by their phytochemical bioactivities, and their chemical compounds are identified in phytochemical investigations and clinical trials $(7,8)$. In addition, increase in the cost of synthetic drugs along with its side effects led to the emergence of the use of natural medicinal resources for human well-being across the globe $(9,10)$. A large part of modern medicine is originated from medicinal plants $(11,12)$. In 2006, the trade value of medicinal and aromatic plants was estimated $\$ 60$ billion, which is still expected to expand significantly by 2050 (13) due to the increasing interest in herbal drugs $(14,15)$.

Harvesting, cultivation, and trade of plants provide very important options for livelihood of millions of rural people, especially women and low-income populations $(16,17)$. In recent decades, scientific growth and commercial interests in developing countries on medicinal plants have been observed (mainly due to the economic potential and the widespread acceptance of plant products) (18). Hence, a lot of investigations have been initiated to validate the effects of these plants $(19,20)$. Native plant sources of a region meet a variety of basic needs such as building materials, food and medicine of that community. The use of plant resources, especially medicinal plants, has led to favourable outcome, including selfsufficiency and economic opportunities for local residents. This can lead to resource management problems in preserved areas and may turn such areas into focal points to harvest selected species. Therefore the debate over preservation of the diversity of growing plants between resource users and managers is likely. A tremendous pressure is brought about by social and economic change to indigenous knowledge, traditional medicine and human cultures and traditions $(21,22)$. According to World Health Organization, traditional medicine refers to the total knowledge, skills, and practices based on indigenous theories, beliefs, and experiences that are used to maintain and improve health. Traditional medicine is well recognized as a type of treatment that is used in different communities, by means of a wide variety of medicinal plants, to treat various diseases (23). Traditional therapists in many indigenous rural communities generally have a high social status in their societies, and therefore have a significant influence on local therapies, so they may be involved in discovering facilities to support new health care plans as well (24). Given the abovementioned, indigenous knowledge is used, alongside medicinal plants, to treat human diseases; however, this knowledge is gradually disappearing, because it is orally, rather than by means of a written system, is transferred from generation to generation (25). Many cultures have extensive unrecorded knowledge about the use of herbal drugs for treatment of diseases (26), and now it is more important than ever to record and preserve the traditional knowledge about medicinal plants to help discover new drugs and possibly to find an enhanced programme of traditional medicine (27). In addition, reporting scientific research results regarding medicinal plants helps preserve an important part of the cultural heritage of indigenous people for future generations. The 1992 Convention on Biological Diversity explicitly acknowledged the key status of native ethnicities and their knowledge about the conservation of genetic resources. According to Article 8 of the Convention, it is a duty of the Member States, within the framework of national law, to respect, preserve and promote the knowledge, methods and innovations of indigenous people, including the forms of life associated with the conservation and sustainable use of biodiversity, and make efforts to preserve, sustain, and disseminate it with the consent and participation of the owners of this knowledge, methods, and innovations and encourage their fair sharing of the benefits of using them (17).

The total value of the imported medicinal plants and plant-derived raw materials into Iran in 2007 was approximately 85 million dollars. Essential oils account for the highest proportion of the imported medicinal plants, so that $\$ 59$ million was allocated to essential oils in that year. These essential oils are mainly used in the cosmetics industry (28). In addition, products from Ferula gummosa, Crocus sativus, Nigella sativa, Carum carvi, Ferula asafoetida, Lawsonia inermis, Myrtus communis, Rosmarinus officinalis, Glycyrrhiza glabra and Mentha sp. are relatively important for export and certain plants such as Matricaria chamomilla, Silybum marianum, Valeriana officinalis, Dracocephalum sp. and Mentha sp. are highly important for medicine and domestic market (29). In general, sustainable development, self-sufficiency, employment (especially for the natives), food and pharmaceutical industries can be greatly assisted by the proper management of resources for the export of medicinal plants (10). With regard to the above-mentioned facts and the importance of medicinal plants in the treatment of various diseases, further studies on indigenous knowledge can help identify new therapeutic effects and contribute to the advancement of the pharmaceutical industry in Iran. In this research, we investigated indigenous knowledge about native human medicine in the Khalil Abad village, Zarrin Dasht County, Fars province of Iran. 


\section{Materials and Methods}

\section{Location and characteristics of the studied grassland}

Khalil Abad basin is located in approximately 35 $\mathrm{km}$ distance to Hajiabad from northwest, in geographical position $54^{\circ} 22^{\prime} 53^{\prime \prime}$ to $54^{\circ} 30^{\prime} 22^{\prime \prime} \mathrm{E}$ and $28^{\circ} 37^{\prime} 55^{\prime \prime}$ to $28^{\circ} 32^{\prime} 37^{\prime \prime} \mathrm{N}$ (the area map is shown in Fig. 1). This region is a central part of Zarrin Dasht County. The area of the basin is $48.66 \mathrm{~km}^{2}$ and main livestock of the region is goat. Predominant herbaceous vegetation of the region are Amygdalus lycioides, Amygdalus scoparia, Convolvulus sp., Astragalus sp. and Tamarix sp. Generally, livestock will be brought for grazing during winter for about 180 days. Most of the total annual rainfall occurs in winter months (61.99\%) and the lowest precipitation is seen in summer months $(2.31 \%$ of the total annual rainfall). Usually, good rainfall occurs during December and January $(22.78 \%)$. Based on the latest population statistics (done in 2010), a total of 315 focal and extended families (a population of 1,198 people) lives in the village. In total, the region's income generating activities include crop activities, livestock breeding, and to a much lesser extent, handicraft activities.

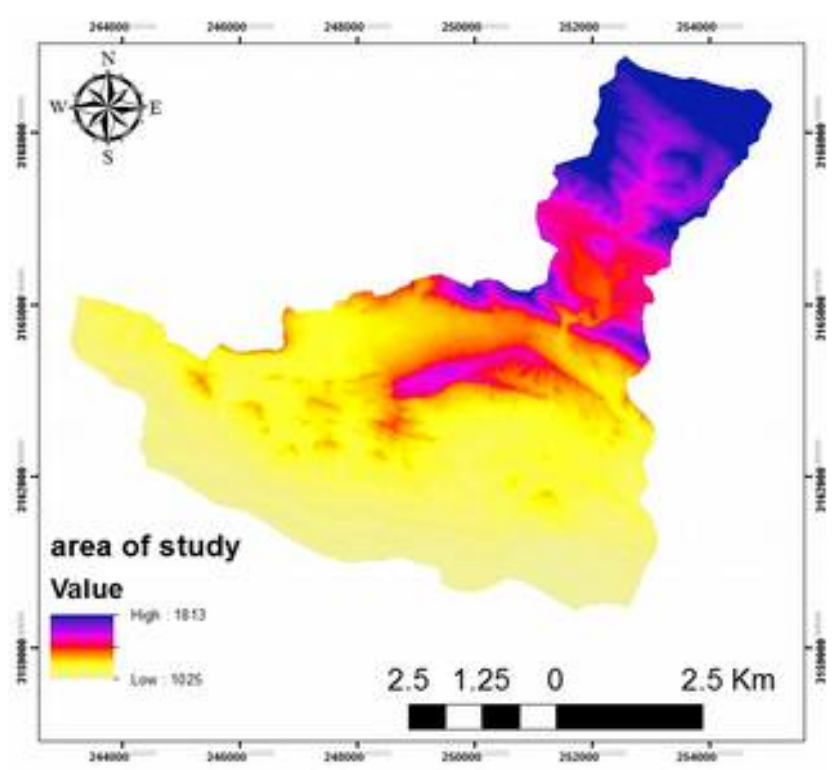

Fig. 1. The location of study area. Map magnification: 5000, the type of winter pasture, the ecological status, altitude: 1500 $\mathrm{m}$, and annual rainfall: 200-250 mm. Source: Ministry of Culture and Tourism of Iran.

\section{Data collection}

Field surveys were conducted and collected information based on questionnaires. Assistance was also taken from experts and also for the identification of medicinal plants.

\section{Sampling method}

In the season when medicinal plants were present, the study team visited the pastures along with experienced local people and all stages including identification, collection, drying, probable sale (some species), maintenance and use were observed and the information of interest were recorded. A questionnaire containing the local name, phenology, description of the habitat, method and time of collection, drying method, storage method, the usable parts of the plant, indications, dosage, and the side effects due to the misuse of the medicinal plants was designed and then completed with the help of local experienced people (34 people were involved) to collect information about their traditional uses. The local groceries of the region were referred to collect information about their price and dosage as well as the method(s) of using them (alone or combined). Interview is very much needed for exploratory botanical research, because it makes easy both for the interviewer to ask the interviewee (narrator) and for the interviewee to remind and make association, and prevents the potential misunderstandings of the interviewer (investigator) and the interviewee (narrator), and gradually makes the interviewer's knowledge about the plants more accurate (32). The data collected throughout the interviews were recorded on the fieldnotes, categorized based on the differences and similarities among the drawn contents and then analyzed.

\section{Results}

So far, no studies have been done on the ethnobotany in the region, and this study recorded large number of new effects of medicinal herbs (the results are given in Supplementary Table 1). In this study, a total of 37 plant species were collected during January to May 2017. It should be noted that some of the plants that inhabit in Khalil Abad village used for nutritional and medicinal purposes were the plants of tropical regions. All the species in this study have been traditionally and locally used for nutritional and medicinal purposes. The botanical name, family, local names, used parts and uses according to indigenous knowledge of the ethnicities living in the Khalil Abad grasslands are shown in supplementary Table 1.

The studied plants in this investigation belonged to annual and perennial grasses, bushes and trees. Among them, the multi-year herbaceous plant species had the highest percentage of use for various purposes. In this study, the collected plants belonged to 30 families, among which the Papilionaceae, Asteraceae, Malvaceae and Chenopodiaceae had the highest contribution. The results of this study indicate that the Khalil Abad grasslands residents used all these plants for various nutritional, medicinal and healthcare purposes, so that out of the 37 species collected, 12 had nutritional and medicinal uses, six were attributed both oral and tonic properties and the remaining species were considered to have 
medicinal uses. The interviewees most often reported gastrointestinal diseases, respiratory infections and temperate disorders as the most common indications for the use of the medicinal plants. In addition, the most commonly used plant parts for nutritional and medicinal purposes were fruits, leaves and root of trees, leaves, stem (including flowering stem), flowers, root and gum in herbaceous and bushy plants.

In Fig. 2, the families and percentages of the effects of medicinal plants in the treatment of diseases are illustrated. Among them, the plants of Asteraceae, Papilionaceae, Labiatae, and Chenopodiaceae had the highest contribution to the treatment of diseases $(10.81 \%, 8.10 \%, 8.10 \%$, and $5.40 \%$, respectively).

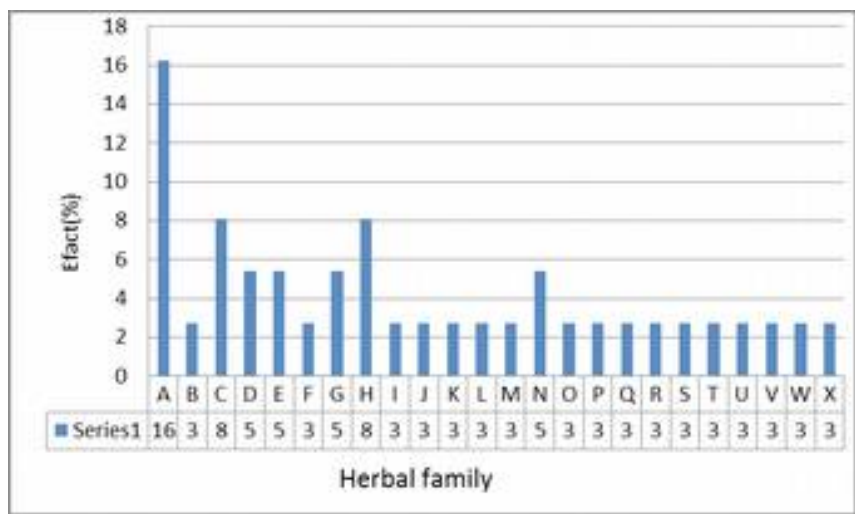

Fig. 2. Families and percentages of the effects of plants in the treatment of diseases A: Lamiaceae, B: Zygophyllaceae, C: Papilionaceae, D: Malvaceae, E: Asteraceae, F: Plantaginaceae, G: Apiaceae, H: Boraginaceae, I: Myrtaceae, J: Moraceae, K: Rhamnaceae, L: Rosaceae, M: Brassicaceae, N: Chenopodiaceae, O: Fumariaceae, P: Anacardiaceae, Q: Cucurbitaceae, R: Agaricaceae, S: Tuberaceae, T: Plantaginaceae, U: Capparidaceae, V: Arecaceae, W: Boraginaceae, X: Polygonaceae.

Fig. 3 shows the percentage use of different parts of the plants. The leaves are the most frequently used parts (29\%), followed by the seeds and the shoots (14\%) and the fruits (12\%).

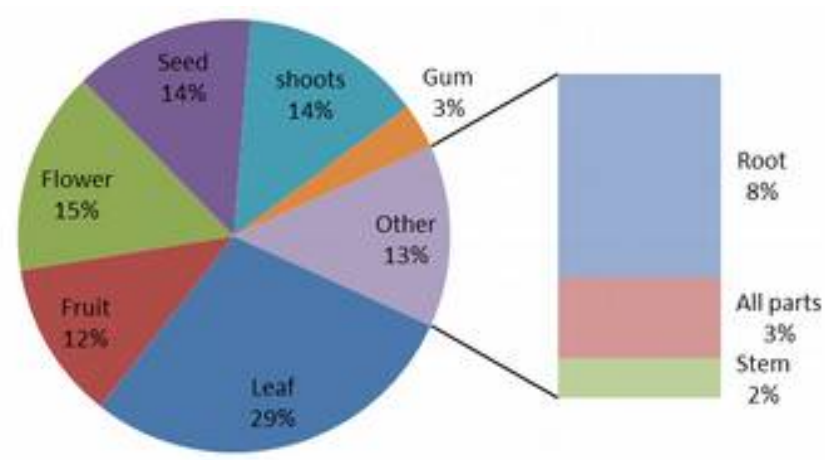

Fig. 3. Use of different plant parts for various purposes

In Fig. 4, the routes of administration of the plants are illustrated, according to which the oral route $(34 \%)$ is the most frequent followed by boiled (32\%).

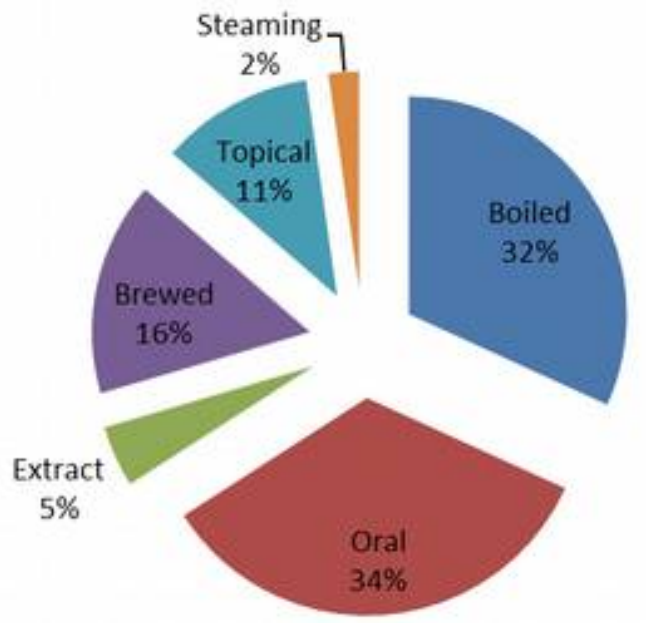

Fig. 4. Routes of administration of the medicine

\section{Discussion}

Inference from the present study is that the Khalil Abad grasslands has a rich source of medicinal plants, covering different aspects of the ethnopharmacology to ethnobotany and ethnoecology. The indigenous knowledge of the region's people about plants is very extensive, so that they have adequate knowledge about plant identification, habitats, and appearance as well as their medicinal and nutritional properties, as most indigenous people of the Khalil Abad village are well familiar with their environment and its constituents. From the indigenous people's perspectives, an object or experience cannot be understood without taking its surrounding into account. Local people's understanding of objects and phenomena is general, so the focus of indigenous botanical knowledge is not just on the plant, but the knowledge also includes the relationship between the plant and other environmental factors associated with it, and perhaps this is why it is often said that they should see the plant in its habitat to know it.

Similar studies in the country also show that the indigenous knowledge of the local people regarding the plants is very high, so that, by using this knowledge, we can easily gain valuable information about the medicinal properties, plant parts, time of growth, best harvest time and areas where the vegetative potential of these plants are achieved within the shortest possible time (30). Medicinal (31) habitat prediction and the likelihood of the occurrence and distribution of plant species are widely used in various fields and are mainly suitable for a large number of applied research in ecology, in particular to describe the needs of plant communities and the physical and chemical environmental factors affecting their occurrence (32). The findings of this research represent another evidence to support the claim that Iran is a region rich in cultural and ethnic diversity that has a unique diversity in climatic conditions and natural ecosystems for the cultivation of medicinal plants. Various geographic 
conditions and different habitats on the one hand and ancient Iranian culture on the other hand, have provided a treasure of popular creativities in the field of ethnobotany and the properties of each plant species. The traditional effects of medicinal herbs in ancient science are being proven in experimental and scientific studies. If land audit, mining, mineralization, the evaluation and exploitation of mineral resources are part of the daily activities of governments as well as the private sector in the country, then by the same token, the indigenous knowledge about valuable and unique plant species should have to be carefully studied. Otherwise, a very important part of the spiritual and natural heritage of the country that the future generations will have to be directly or indirectly dependent upon will be ignored and forgotten.

\section{Conclusion}

The results of this study indicate that the residents of Khalil Abad village uses medicinal plants for an array of nutritional and medicinal purposes. The medicinal plants of indigenous knowledge of this region can be used as a source for preparation and use of new drugs. Oral tradition of the local people in other regions of the country also has vast information about the use of medicinal as well as other plants which needs to be documented and utilized for their effective use to sustain the plants based healthcare system, particularly in the villages.

\section{Acknowledgements}

This study was sponsored by Khatam-ol-Anbia University of Technology Behbahan, Behbahan, Iran.

\section{Conflict of interest}

The authors declared that they have no conflict of interest.

\section{Authors' Contribution}

FA, KK and KS designed the objectives and plan of work. KK, HK carried out the work, analyzed the data and wrote the manuscript. FA and SSH helped in data analysis, interpretation and manuscript correction.

\section{References}

1. Jamshidi-Kia F, Lorigooini Z, Amini-Khoei H. Medicinal plants: past history and future perspective. J Herbmed Pharmacol 2018; https://doi.org/10.15171/jhp.2018.01
2. Hocking GM. Pakistan medicinal plants-IV, Plant Foods for Human Nutrition (Formerly Qualitas Plantarum) 1962; 9: 103-119. https://doi.org/10.1007/BF01105184

3. Sarrafchi A, Bahmani M, Shirzad H, Rafieian-Kopaei M. Oxidative Stress and Parkinson's Disease: New Hopes in Treatment with Herbal Antioxidants. Current Pharmaceutical Design 2016; 22(2):238-46. https://doi.org/10.2174/1381612822666151112151653

4. Abbasi N, Akhavan MM, Rahbar-Roshandel N, Shafiei M. The effects of low and high concentrations of luteolin on cultured human endothelial cells under normal and glucotoxic conditions: Involvement of integrin-linked kinase and cyclooxygenase-2. Phytotherapy Research 2014; 28(9): 1301-1307.

5. Shokri Z, Khoshbin M, Koohpayeh A, Abbasi N, Bahmani F, Rafieian-Kopaei M, Beyranvand F. Thyroid diseases: Pathophysiology and new hopes in treatment with medicinal plants and natural antioxidants. International Journal of Green Pharmacy 2018; 12(3): 473-482.

6. Rahimi-Madiseh M, Lorigoini Z, Zamani-Gharaghoshi $\mathrm{H}$, Rafieian-kopaei M. Berberis vulgaris: specifications and traditional uses. Iran J Basic Med Sci 2017; 20(5): 569-87.

7. Hosseini Z, Lorigooini Z, Rafieian-Kopaei M, Shirmardi HA, Solati K. A review of botany and pharmacological effect and chemical composition of echinophora species growing in Iran. Pharmacognosy Research 2017; 9(4):305-12. https://doi.org/10.4103/pr.pr 2217

8. Bahmani M, Sarrafchi A, Shirzad H, Asgari S, RafieianKopaei M. Cardiovascular toxicity of cyclooxygenase inhibitors and promising natural substitutes. Current Pharmaceutical Design 2017; 23(6):952-60. https://doi.org/10.2174/1381612822666161006144942

9. Gilani SA, Kikuchi A, Shinwari ZK, Khattak ZI, Watanabe KN. Phytochemical, pharmacological and ethnobotanical studies of Rhazya stricta Decne, Phytotherapy Research 2007; 21:301-307 https://doi.org/ 10.1002/ptr.2064

10. Newman DJ, Cragg GM. Natural products as sources of new drugs over the 30 years from 1981 to 2010. Journal of Natural Products 2012; 75:311-335. https://doi.org/10.1021/np200906s

11. Farnsworth NR, Soejarto DD. Global importance of medicinal plants. Conservation of Medicinal Plants 1991; 25-51. https://doi.org/10.1017/CBO9780511753312.005

12. Lange D. Trade in plant material for medicinal and other purposes. Traffic Bullettin 1997; 17: 21- 32.

13. Khan B, Abdukadir A, Qureshi R, Mustafa G. Medicinal uses of plants by the inhabitants of Khunjerab National Park, Gilgit, Pakistan. Pakistan Journal of Botany 2011; 43: 2301-2310.

14. Karimi A, Mohammadi-Kamalabadi M, Rafieian-Kopaei M, Amjad L, Salimzadeh I. Determination of antioxidant activity, phenolic contents and antiviral potential of methanol extract of Euphorbia spinidens Bornm (Euphorbiaceae). Tropical Journal of Pharmaceutical Research 2016; 15(4):759-64. https://doi.org/10.4314/tjpr.v15i4.13

15. De Boer HJ, Lamxay V, Björk L. Comparing medicinal plant knowledge using similarity indices: A case of the Brou, Saek and Kry in Lao PDR. Journal of Ethnopharmacology 2012; 141:481-500. https://doi.org/10.1016/j.jep.2012.03.017

16. Bahmani M, Zargaran A, Rafieian-Kopaei M. Identification of medicinal plants of Urmia for treatment of gastrointestinal disorders. Revista 
Brasileira de Farmacognosia 2014; 24(4):468-80 https://doi.org/10.1016/j.bjp.2014.08.001

17. Sher H, Aldosari A, Ali A, de Boer HJ. Indigenous knowledge of folk medicines among tribal minorities in Khyber Pakhtunkhwa, northwestern Pakistan. Journal of Ethnopharmacology 2015; 166:157-167. https://doi.org/10.1016/j.jep.2015.03.022

18. Jalaly L, Sharifi G, Faramarzi M, Nematollahi A, Rafieian-Kopaei M, Amiri M, et al. Comparison of the effects of Crataegus oxyacantha extract, aerobic exercise and their combination on the serum levels of ICAM-1 and E-Selectin in patients with stable angina pectoris. Daru 2015; 23(1):54. https://doi.org/10.1186/s40199-015-0137-2

19. Karami S, Roayaei M, Hamzavi H, Bahmani M, Hassanzad-Azar $\mathrm{H}$, Leila $\mathrm{M}$, et al. Isolation and identification of probiotic Lactobacillus from local dairy and evaluating their antagonistic effect on pathogens. International Journal of Pharmacological Investigation 2017; 7(3):137-41. https://doi.org/10.4103/iphi.JPHI 817

20. Sher H, Barkworth ME. Economic development through medicinal and aromatic plants (MAPs) cultivation in Hindu Kush Himalaya mountains of District Swat, Pakistan. Journal of Mountain Science 2015; 12:12921301. https://doi.org/10.1007/s11629-014-3247-2

21. Sher H, Barkworth ME, de Boer HJ. Medicinal and aromatic plant cultivation in the Swat valley, northwestern Pakistan, for economic development and biodiversity conservation. Genetic Resources and Crop Evolution 2017; 64(2):237-245. https://doi.org/ 10.1007/s10722-015-0346-Z

22. Samie A, Obi CL, Bessong PO, Namrita L. Activity profiles of fourteen selected medicinal plants from rural Venda communities in South Africa against fifteen clinical bacterial species. African Journal of Biotechnology 2005; 12: 1443-1451.

23. Cheikhyoussef A, Shapi M, Matengu K, Ashekele HMU. Ethnobotanical study of indigenous knowledge on medicinal plant use by traditional healers in Oshikoto region, Namibia. Journal of Ethnobiology and Ethnomedicine 2011; 7:10. https://doi.org/10.1186/17464269-7-10

24. Kaido TL, Veale DJH, Havlik I, Rama DBK. Preliminary screening of plants used in South Africa as traditional herbal remedies during pregnancy and labour. Journal of Ethnopharmacology 1997; 55:185-191. https://doi.org/ $\underline{10.1016 / S 0378-8741(96) 01499-7}$
25. Offiah NV, Makama S, Elisha IL, Makoshi MS, Gotep JG, Dawurung CJ, Oladipo OO, Lohlum AS, Shamaki D, Ethnobotanical survey of medicinal plants used in the treatment of animal diarrhoea in Plateau State, Nigeria. BMC Veterinary Research 2011; 7:36. https://doi.org/10.1186/1746-6148-7-36

26. Koné MW, Atindehou KK. Ethnobotanical inventory of medicinal plants used in traditional veterinary medicine in Northern Côte d'Ivoire (West Africa). South African Journal of Botany 2008; 74:76-84. https://doi.org/ 10.1016/j.saib.2007.08.015

27. Ebrahimi A. Effective factors in identifying and determining the target markets for medicinal plants at the national and international levels. C2008 [cited 2019 April 10] Available from: http://plant.mihanblog.com/post/452

28. Shayganni E, Bahmani M, Asgary S, Rafieian-Kopaei M. Inflammaging and cardiovascular disease: Management by medicinal plants. Phytomedicine 2016; 23(11):11191126. https://doi.org/10.1016/j.phymed.2015.11.004

29. Ebrahimi A. The Place of the Economy of Medicinal Plants in Iran and the world and the necessity of observance of the principle of sustainable development. At: Summary of Articles of the First International Symposium on Traditional Medicine and Mortgages University of Medical Sciences, Beheshti University of Medical Sciences, Tehran, Iran Research, Office of International Relations; 2000.

30. Bahmani M, Avijgan M, Hossaini SR, Najafzadeh Varizi, H, Bahmani E, Mehrzadi S. Traditional application of medicinal plants in southern area of Ilam province for treatment diseases and clinical syndromes in small ruminants. Journal of Herbal Drugs (An International Journal on Medicinal Herbs) 2010; 1(2), 49-57.

31. Zolfaghari B, Sadeghi M, Tiri I, Yousefali Tabar M. Collection, Identification, and Evaluation of the Traditional Applications of Some Plants of Babol. Journal of Islamic and Iranian Traditional Medicine 2012; 3(1):113-124.

32. Elith J, Leathwick JR. Species Distribution Models: Ecological Explanation and Prediction Across Space and Time. Annual Review of Ecology, Evolution and Systematics. 2009; 40:77-697. https://doi.org/10.1146/annurev.ecolsys.110308.120159 